\title{
Musical Collection from Latin CATHEdRAL in LViv AS THE SOURCE OF THE HiSTORY OF THE CATHEDRAL ChOIR AND ORCHESTRA
}

The article presents unknown sources to the history of music in Latin Cathedral in Lviv in the $19^{\text {th }}$ and early $20^{\text {th }}$ century, both cathedral choir and orchestra. The author focuses on the musical activity of priests serving in the temple as well as on Henryk Jarecki. Latin Cathedral in Lviv may be considered as one of the most important Catholic temples on the territory of the Polish-Lithuanian Commonwealth. The city itself in the $19^{\text {th }}$ and $20^{\text {th }}$ centuries was a multicultural centre, in which the tradition of Polish, Ukrainian, Jewish and Armenian nations and their religions co-existed and influenced each other.

Keywords: Latin Cathedral, Cathedral choir and orchestra, Henryk Jarecki`s music

Formulation of the problem. Even though the Latin Cathedral has a history dating back many centuries, still very little is known about its music. One of the earliest sources proving tradition of performing polyphonic compositions is Kyriale from 1631 (held currently at Scientific library of Lviv National University Наукова бібліотека Львівського національного університету, ms. 1559/IV). Its repertoire is a proof of a great impact of Wawel's Cathedral on Latin Cathedral in Lviv. Also very little is known about the musicians in Latin Cathedral in the Middle Ages, or the Renaissance as well as in later periods. The common belief is that during the second half of the $19^{\text {th }}$ and $20^{\text {th }}$ centuries there was neither choir nor orchestra in the Latin Cathedral. In fact, richness of the musical tradition of the city disposes the researchers to focus rather on the subject of secular music, moving sacred music aside. Even though the history of the city was very complicated, many sources are preserved and awaiting to be rediscovered.

Analysis of recent research. The change of borders in 1945 gravely influenced the archive resources. Although it causes many difficulties in research on musicological subjects, it also opens a new common space for the cooperation between researchers from different countries.

Musical collections can be found in many institutions of the city. Among libraries and archives, there are also sources unknown to the researchers deposited in Latin Cathedral. In the current state of research, the provenance of majority of them remains unknown. A significant percentage of identified sheets comes from the Latin Cathedral, what is proven by precise provenance note.

In the study of historical and musical issues, the author of the paper relies on the following sources: the catalog of the clergy from the archbishopric of Lviv; archival documents of the Latin Cathedral; note collection of the Latin cathedral; the publication "Szkoła dla samouków na klawiaturowym instrumencie i śpiewu" [15], "Cantionale Ecclesiasticum" [13], the leading journal "Muzyka Kościelna Parafialna", the memoirs recorded by Leonard Soletsky in 1882 [14, 7].

Objective of the study. Present to the general public the musical collection of the Latin Cathedral and the musical component of Catholic worship. To reveal the historical aspect of the 
development of the musical performance of the service component and its repertoire during the topic under study.

Presenting main material. One of the oldest examples of such sources is "Missa Pastoralis in D" composed by František Brixi. In the right bottom corner, there is the inscription: "Proprietas Ecc[lesiae] Metrop [olitanae] Baraniecki Can[icus] [et] Rector Chori". Based on this information, it is possible to date this manuscript.

The first list of the clergy (schematismus) in the Roman Catholic Archdiocese of Lviv was published in 1814. It does not contain any information about Łukasz Baraniecki, since at this time he was only 16 years old, nor about any person serving as the rector chori or cantor chori. The next catalogue of clergy was published in 1833. It contains a note that Baraniecki was ordained to the priesthood in 1822, and in 1833 was working as a parson in Hodowica (currently in the Pustomyty Raion, Lviv Oblast). In the index from 1837, he is mentioned as Canonicus et Assessor Consistorii, however there is still lack of information about a function called rector chori. The first person confirmed to be a cantor chori is mentioned, however, just in the following catalogue of clergy from 1839 and is known as Henryk Pertak. We know very little about his life and musical activity. He was born in 1807 and ordained to priesthood in 1832. Until 1837, he worked as a vicar in the parish in Jazłowiec (currently in the Buchach Raion, Ternopil Oblast). After this time, he was moved to the Latin Cathedral, where he served as cantor chori. In the $1850 \mathrm{~s}$, he also worked as a teacher in cathedral school. In 1857, he was nominated a parson in the Church of Our Lady of the Snows in Lwów, where he stayed until his death in 1878.

In 1839, Lukasz Baraniecki is already known to be a parson in Latin Cathedral. We can assume that he held the function of cantor chori before that date, but certainly after 1833. It means that the manuscript was written down in the late 1830s. What seems to be interesting, the musical collection of Latin Cathedral was extended even in later years. On the dust jacket of "Antiphona et Benedictus pro feria quinta in Caena Domini a Quattro Voci" by Giorgio de Reüttern, an inscription was written: "Proprietas Ecc[lesiae] Metrop[olitanae] Baraniecki Can [onicus] et Par [ochus]". That means that the manuscript could have been written down between 1839 and 1850, so before Baraniecki became an archbishop of the Archdiocese of Leopolis. It appears obvious that cantor chori was not a function equal to Kapellmeister. Probably, he was in charge of music in Latin Cathedral and served also as a cantor of the Cathedral Chapel. Especially in later years, when the best musicians in the city were hired to provide musical service for the liturgy, the elaborated function had to be secondary. Our attention is also drawn to the fact that abovementioned composers were very important in this period of time. Johann Georg Reutter (1708-1772) was not only a composer, but also a Kapellmeister in St. Stephen's Cathedral in Vienna. That partly proves that the best repertoire of the Austrian Empire was willingly performed in the capital of Galicia.

Thanks to the catalogues of the clergy from Archdiocese of Lviv, it is possible to provide a full list of priests who were appointed as cantor chori. As mentioned earlier, after Łukasz Baraniecki this function was held in years 1837-1857 by Henryk Pertak. Later, until 1871, the position was taken up by Albin Hauptmann. Again, very little can be said about him. He was born in 1827 and ordained to priesthood in 1850. Around 1871, Hauptmann was nominated a parson in Dawidów (currently in the Pustomyty Raion, Lviv Oblast), where he stayed until his death in 1876. In fact, not only was he a cantor chori, but he also served as magister cantus in an Archdiocesan seminary.

Beginning from the year 1862 (except for Jan Stachow and Teofil Moszyński), all priests shared these two functions. Hauptmann may also be considered as a composer. Among the $19^{\text {th }}$ century musical collection from Latin Cathedral, there is at least one mass for choir and orchestra that may be attributed to him. In the current state of research, it is impossible to confirm this attribution as it requires further studies. In years 1871-1875, the function was held by Jan Stachow. 
In the following years, until 1883, he was replaced by Leonard Solecki. He is known especially as a publisher of "Szkoła dla samouków na klawiaturowym instrumencie i śpiewu" [15], "Cantionale Ecclesiasticum" [13] and the trailblazing periodical "Muzyka Kościelna Parafialna", of which idea later was acquired by Surzyński. In 1884, Teofil Moszyński was nominated as cantor chori, but later, until 1887, there was a vacancy. From 1888 to 1892 , the function was held by Julian Kamiński. After a vacancy in years 1894-1896, Ludwik Scherff was nominated. One can assume that he was also a composer, since there is a musical piece signed with his name. However, this issue requires further studies. The last known cantor chori was Rudolphus Nowowiejski, who held the function in years 1911-1912. Rudolf was a brother of a popular composer Feliks Nowowiejski. He also was an author of lyrics to at least two of his brother's compositions, from which the Hymn of the Seminary in Lwów is kept among other musical items from Latin Cathedral.

Thanks to the preserved musical compositions, the amount of instruments used in the cathedral orchestra in the 1830s can be evaluated. Mentioned earlier Brixi's Missa Pastoralis is a compositions for Canto, Alto, Basso, Due Violini, Due Corni con Organo. Reüttern's "Antiphona et Benedictus" is a set for four voices a cappella. Unfortunately, other music sheets from these period of time do not have any provenance note. However, among them, there are compositions for small set of voices, ex. W.A. Mozart's "Missa F-dur" for 4 voices and Due Violini col Organo. This brings an idea of a rather small ensemble in Latin Cathedral in the first half of the $19^{\text {th }}$ century.

The situation changed completely in the last decades of the $19^{\text {th }}$ century. At the unknown time, Henryk Jarecki got involved in the musical matters in the Latin Cathedral. Jarecki was born in 1846. He was a favourite pupil of Stanisław Moniuszko. Not only did he compose a music, but also performed it in many centres. In fact, he is mostly known as the conductor of the opera in Lwów from 1872. His connection with the cathedral choir and orchestra still requires further studies. In fact, one can assume that in the late $19^{\text {th }}$ century the Latin Cathedra did not have its own instrumental ensemble and used an orchestra from the opera. In this very time, the opera ensemble used a Skarbkowski Theatre in Lwów. A search query in the $19^{\text {th }}$ century press proves, however, that the cathedral orchestra was a separate ensemble, though sharing members with the orchestra of the opera cannot be excluded. Designating which musical items were the property of Henryk Jarecki appears to be rather easy. On majority of them, a seal "Henryk Jarecki" was put.

On the dust jackets of many compositions from the musical collection of Latin Cathedral, inscriptions proving dates of performances were added. Mozart's "Missa F-dur" was performed at least 6 times: in 1822, 1823, 1825, 1826, 1835 and 1876. On the dust jacket of Moniuszko's "Missa in Es-dur" the inscription was written: "Wykonana dnia 12 października $1896 \mathrm{r}$. [w] Archikatedrze św. Jura na Jubileusz 300. lecia Unii Brzeskiej", which means that this mass was performed in St. George's Cathedral in Lwów at the jubilee celebration of the Union of Brest. This fact was confirmed by the relation published in "Gazeta Lvivska" stating that during the solemn mass "the adequate compositions" were performed by the Cathedral Choir conducted by Henryk Jarecki $[5,4]$. Thanks to the press, we know that one of the most important solemnity, during which cathedral choir used to sing every year, was the birthday of Emperor Franz Joseph. On this occasion, every year after the liturgy people sang "Te Deum laudamus", after which the choir performed the national anthem [6,3]. What is worth noticing is the fact that Jarecki was also involved in the activity of Lwowskie Towarzystwo Śpiewackie, with which he performed Kurpiński's Mass in 1884, playing organ part. Together with Lutnia choir, he performed Kuriński's Oratorio. In later years, Jarecki was also known as a conductor of Lutnia choir. Just in 1883, together with Stanisław Cetwiński, the Lutnia's conductor, they organised a new choir called "The Mixed Choir". This ensemble consisted of male members from Lutnia and ladies "already fluent in singing". The city casino was appointed as a place of rehearsals on each Wednesday. Together with 
this choir, Jarecki performed - among others - Mendelssohn's "Elijah". The music sheets from this performance were incorporated into the cathedral collection.

Thanks to other dates which were noted on music sheets, we also know that Rossini's "Missa Solemnis" (or in fact: "Le Petite messe solennelle") was a very popular composition, performed for the first time in 1877, later 4 times in 1882 and once in 1883. Gruber's "Requiem" was repeated on the anniversary of Empress Elisabeth death (on the $10^{\text {th }}$ of September) in years 1907-1909 and in 1911. This composition was also performed in years 1907-1910 and 1912-1913 on the memorial of All Souls' Day (on the $2^{\text {nd }}$ of November) and on the $28^{\text {th }}$ of June 1909 , which was the $34^{\text {th }}$ anniversary of Emperor's Ferdinand I death. According to the press, the prayers for the peace of the soul of Emperor Ferdinand took place in all three cathedrals in the city [7, 3]. In 1902, the Cathedral choir and the orchestra conducted by Henryk Jarecki performed in Latin Cathedral during the solemn anniversary of the Lwów Oath, however the repertoire from this event remains unknown $[12,1]$.

Performing mentioned Gruber's "Requiem" requires (according to preserved voices): Violino I, Violino II, Viola, Basso and Organo. According to the published score, the compositions requires also two clarinets, two horns and trombone. That leads to two possible conclusions. Either not all the voices have been preserved or the cathedral ensemble performed only selected voices from the entire compositions. However, it is more likely that rather in the late $19^{\text {th }}$ century the size of the orchestra ensemble in Latin Cathedral did not enlarge.

Very valuable information about music is a flashback written down by Leonard Solecki in 1882. He recalled Franciszek Wierzchlejski's jubilee of 50 years of the ordination to priesthood, who was an Archbishop in Lwów in the mentioned year 1876. During that solemn mass, cathedral choir and orchestra conducted by Henryk Jarecki with the help of other musicians (perhaps the musicians from the opera?) performed "one of the most glamorous masses". Solecki does not provide us with the authorship of the composition but only with the information that the Agnus Dei was "lovely" $[14,7]$.

Again, the exact date when Jarecki stopped being in charge of Cathedral choir remains unknown. Probably, at the very end of his life, he got engaged in music at Dominican Order's convent $[9,162]$. In 1913, Stefan Surzyński became the new conductor of the choir and Cathedral organist. After his death in 1919, at the current state of research there are no further information about any music ensemble in Latin Cathedral.

From the early $20^{\text {th }}$ century, the Lutnia Choir was involved in performing music in the Latin Cathedral. Probably, from 1925 Lutnia sung during every Sunday mass and during solemnities both religious and national. The repertoire in the temple did not change very much -masses by Mozart and Moniuszko were still performed - but the repertoire was enriched by Gounod's and Perosi's masses and Rheinberger's "Missa solemnis in C", of which performances we had no previous information [1,114-115]. Only in 1928, the choir performed compositions of Pembauer, Messner, Palestrina, Lotii, Haendel, Mozart, Moniuszko, Münheimer, Jarecki, Niewiadomski, Surzyński, Nowowiejski, Rutkowski, Gall, Kagerer, Perosi, Prosnak, Rączka and Różycki [2, 205-206].

In the 1920s, Józef Nowakowski became the organist of Latin Cathedral. In his possession was the music sheet of an oratorio "Śluby Królewskie" composed by Mieczysław Sołtys, whose pupil he was $[16,81]$. It remains unknown whether he took part in performing this piece, but it proves a long-lasting tradition of music in Lwów. Nowakowski became a director of a Cathedral's school $[3,407 ; 8,31]$. Very little is known about music education there. In the late $19^{\text {th }}$ century, the organ teacher was Jan Piotrowski. The number of students was diversified and varied among 30 and 44. The school used to heave its own pipe organs build by Roman Ducheński around 1880 [8, 31$]$.

Finally, it should be stated that the issue of the history of music in Latin Cathedral in presented period of time is a very complex matter. Thanks to the recently unknown sources, several 
new facts have come to the light. It appears that until the early $20^{\text {th }}$ century a choir and a small orchestra conducted for many years by Henryk Jarecki existed in the church. The repertoire was also very diversified and consisted of compositions of local origin as well as of the most recognised works in mentioned period in Western and Central Europe.

The musical collection discussed in this article consists mostly of disordered documents, so using them in the further research appears to be impossible. A current research plan is to order mentioned sources and prepare a full catalogue of them. Since information mentioned in this article are the result of recent studies, supplementing missing details will require further search query.

\section{REFERENCES}

1. Lipanowicz, S. (1928), Lutnia-Macierz, Almanach Lwowski “Ateneum”, Towarzystwo Wydawnicze Ateneum, Lwów, 204 p. [in Polish]

2. Lipanowicz, S. (1929), Lutnia-Macierz, Almanach Lwowski “Ateneum”, Towarzystwo Wydawnicze Ateneum, Lwów, 282 p. [in Polish]

3. Chodynicki, I. (1929), Historya stołecznego królestw Galicyi i Lodomeryi miasta Lwowa od założenia jego aż do czasów teraznieyszych, Nakład Karola Bogusława Pfaffa, Lwów, 466 p. [in Polish]

4. Feicht, H. (2008), Wspomnienia, Wydawnictwo Instytutu Teologicznego Księży Misjonarzy, Kraków, 220 p. [in Polish]

5. Jubileusz Unii brzeskiej , (1896), Gazeta Lwowska, no. 235, 12 p. [in Polish]

6. Kronika, (1906), Gazeta Lwowska, no. 227, 14 p. [in Polish]

7. Kronika, (1909), Gazeta Lwowska, no. 145, 12 p. [in Polish]

8. Kaliberda, S. (2014), Orhany Lvova i Halychyny, Vydavnytstvo Apriori, Lviv,. 448 p.) [in Ukrainian] 9. Piekarski, M. (2018), Muzyka we Lwowie. Wydawnictwo Akademickie Sedno, Warszawa,. 354 p. [in Polish]

9. Piekarski, M. (2017), Przerwany kontrapunkt. Adolf Chybiński i początki polskiej muzykologii we Lwowie 1912-1944, Wydawnictwo Aspra-JR, Warszawa, 462 p. [in Polish]

10.Piekarski, M. (2009), Z muzycznej przeszłości lwowskich kościołów katolickich, Rocznik lwowski 2008-2009, Instytut Lwowski, Warszawa, 372 p. [in Polish]

11.Obchody narodowe, (1902), Słowo Polskie, no. 215. 4 p. [in Polish]

12.Solecki, L. (1878), Cantionale Ecclesiasticum, Nakład Leonarda Soleckiego, Lwów, 328 p. [in Latin]

13.Solecki, L. (1883), Kalendarz wydawnictwa Muzyki Kościelnej Parafialnej na rok pański, Drukarnia K. Pillera, Lwów, 186 p. [in Polish]

14.Solecki, L. (1883), Szkoła dla samouków na klawiaturowym instrumencie i śpiewu, Nakład Muzyki Kościelnej, Lwów, 50 p. [in Polish]

15.Sołtys, M. (2008), Tylko we Lwowie. Dzieje życia i działalności Mieczysława i Adama Sołtysów. Zakład Narodowy im. Ossolińskich, Wrocław, 224 p. [in Polish]

\section{Стаття надійшла до редакиії 23.01.2018 p.}

\section{А.-Е. ГОДЕК}

https://orcid.org/0000-0002-3890-7260

\section{МУЗИЧНА КОЛЕКЦІЯ ЛАТИНСЬКОГО СОБОРУ У ЛЬВОВІ ЯК ДЖЕРЕЛО ІСТОРІЇ ЦЕРКОВНОГО ХОРУ ТА ОРКЕСТРУ}

Хоч Латинському кафедральному собору у Львові присвячено багато досліджень та розвідок, питання музики, яка виконувалась у ньому, надалі залишається невивченим, що складає актуальність дослідження. Методологія роботи грунтується на поєднанні джерело- 
знавчих, аналітичних та компаративних методів. Шляхом пошуку, аналізу віднайдених та на підставі збережених музичних документів XIX та XX століть автор представляє свої знахідки та висновки щодо хору та кафедрального оркестру, які існували та діяли в той час. Під кінець XIX століття керівником кафедрального музичного колективу став Генрик Ярецкі - відомий композитор та диригент, учень Станіслава Монюшка. Насамперед він відомий своєю роботою у львівській опері. Питання його зв'язків з Латинським кафедральним собором досі залишалося без відповіді. У XX столітті керівництво соборною кафедрою взяв на себе Стефан Сужинський, який раніше був органістом у соборі в Тарнові. Музику в цьому найважливішому Львівському костелі багато років виконував чоловічий хор "Лютня", якому належить першість у представленні багатьох прем'єр, у тому числі творів Мечислава Солтиса.

Результати дослідження. На підставі записів, розміщених на полях та обкладинках збережених нот, представлено коротку хроніку діяльності колективів собору, а також їх репертуар. На підставі каталогів римо-католицького духовенства було створено список священиків, відповідальних за музику, виконувану в соборі, серед інших - Леонард Солецький, видавець журналу, присвяченого церковній музиці та численним церковним щоденникам, або священик Рудольф Нововейський, брат видатного польського композитора Фелікса Нововейського.

Висновок. Пошуки архівних документів для дослідження виявили певну кількість нових матеріалів, які стосуюься історії музичних колективів собору, але оскільки музична колекція $є$ зовсім невпорядкованою, її використання $\epsilon$ складним для подальшого вивчення. Представлена та проаналізована тема дослідження є результатом запиту, здійснюваного автором упродовж кількох років в архівних колекціях на територіях Польщі та України, що може мати вагому значимість для виявлення історичної правди. Результати дослідження дають новий погляд на репертуар, виконуваний у соборі та у Львові з другої половини ХІХ століття до 1939 року.

Ключові слова: Латинський кафедральний собор, Львів, хор та кафедральний оркестр, музика Генрика Ярецькі.

\section{А.-Э. ГОДЕК}

https://orcid.org/0000-0002-3890-7260

\section{МУЗЫКАЛЬНАЯ КОЛЛЕКЦИЯ ЛАТИНСКОГО СОБОРА ВО ЛЬВОВЕ КАК ИСТОЧНИК ИСТОРИИ ЦЕРКОВНОГО ХОРА И ОРКЕСТРА}

Хотя Латинскому кафедральному собору во Львове посвящено много исследований и статей, вопрос музыки, которая исполнялась в нем, продолжает оставаться неизученным, что составляет актуальность исследования. Методология работы основывается на сочетании источниковедческих, аналитических и компаративных методов. Путем поиска, анализа найденных и на основании сохранившихся музыкальных документов XIX и XX веков автор представляет свои находки и выводы относительно хора и кафедрального оркестра, существовавших и действовавших в то время. К концу XIX века руководителем кафедрального музыкального коллектива стал Генрик Ярецки - известный композитор и дирижер, ученик Станислава Монюшко. Прежде всего он известен своей работой в львовской опере. Вопрос его связей с Латинским кафедральным собором до сих пор оставался без ответа. В XX веке руководство соборной кафедрой взял на себя Стефан Сужинський, который ранее был органистом в соборе в Тарнове. Музыку в этом важнейшем Львовском костеле много лет исполнял мужской хор "Лютня", которому принадлежит первенство в представлении многих премьер, в том числе произведений Мечислава Солтыса. 
Результаты исследования. На основании записей, размещенных на полях и обложках сохранившихся нот, представлена краткая хроника деятельности коллективов собора, а также их репертуар. На основании каталогов римско-католического духовенства был создан список священников, ответственных за музыку, исполняемую в соборе, среди которых Леонард Солецкий, издатель журнала, посвященного церковной музыке и многочисленным церковным дневникам, или священник Рудольф Нововейский, брат выдающегося польского композитора Феликса Нововейского.

Вывод. Поиски архивных документов для исследования выявили определенное количество новых материалов, касающихся истории музыкальных коллективов собора, но поскольку музыкальная коллекция является совсем неупорядоченной, ее использование является сложным для дальнейшего изучения. Представленная и проанализированная тема исследования является результатом запроса, совершаемого автором на протяжении нескольких лет в архивных коллекциях на территориях Польши и Украины, что может иметь весомую значимость для выявления исторической правды. Результаты иследования дают новый взгляд на репертуар, исполнявшийся в соборе и во Львове со второй половины XIX века до 1939 года.

Ключевые слова: Латинский кафедральный собор, Львов, хор и кафедральный оркестр, музыка Генрика Ярецки.

Andrzej Edward Godek, PhD, a choir conductor at Blessed Aniela Salawa Parish (Kraków). Анджей Едвард Годек, кандидат мистецтвознавства, диригент хору церкви Благословенної Аніели Салаві Паріш (Краків). email: andres.godek@gmai.com 